\title{
Local Self-Government or Local Co-Governance?
}

\author{
ASBJØRN RøISELAND
}

\begin{abstract}
This article discusses "local self-government", a core concept in a Charter of the Council of Europe, and it departs from the debate in the Norwegian Parliament about constitutional protection of local self-government. Such a change has recently been voted down, and this serves as an opportunity to question the idea about local selfgovernment in a time when there are claims about a shift from government to governance. The article provides some examples of cogovernance in Norway, and argues that the meaning given by "local self-government" is not obvious. It also points to some possible issues in a future revision of the Charter mentioned above.

KEYWORDS: • self-government • co-governance • governance • Norway $\bullet$ Council of Europe
\end{abstract}

Correspondence Address: Asbjørn Røiseland, Ph.D., Faculty of Social Sciences, Bodø University Colege, N-8049 Bodø, Norway, email: asr@hibo.no. 


\section{Introduction}

Despite widely recognised as a highly decentralised country, and unlike its Scandinavian neighbours, Norwegian local government has no formal constitutional status. Reading the 1814 Constitution leaves one with the impression that in a territorial sense, Norway is governed from the capital by the King and Parliament. After municipalities had been formed by law in 1837, some leading parliament members truly saw that as a fulfilment of the constitution made a few years earlier. However, the constitution has never been amended to include municipalities.

On several occasions in modern times, a change to the constitution has been proposed by clearly stating the idea and value of local self-government. The argument is twofold. First, there is a general feeling that the constitution should reflect realities, and since one tends to see Norway as having municipalities with a separate role vis-à-vis the central government, the present constitution does not seem to mirror the actual role of municipalities. Second, propelled by the European Charter of Local Self-Government, ratified by Norway in 1989, it is argued that clear stating of local self-government in the constitution is a necessary act in order to implement the Charter. This argument refers to Article 2 of the Charter, stating that "the principle of local self-government shall be recognised in domestic legislation, and where practicable in the constitution" (Council of Europe 1985).

Despite these arguments, as late as May 2007, the Norwegian Parliament voted down the proposal set forth by the members of various political parties. During the debate, it became clear that the basic principle of local self-government was shared by the majority of Members of Parliament, but there were different opinions about the formulation of this principle. As a compromise, the Parliament made a unanimous decision to request a report on the consequences of such a constitutional change. So far, not much has happened, but sooner or later there will likely be a public discussion about the constitutional status of local selfgovernment in Norway.

The Norwegian parliamentary discussion gives an opportunity to reflect on the basic concept of local self-government, and seen in relation to the claimed shift from government to governance in the subject literature, to discuss the meanings and relevance of the concept. By way of empirical examples, the following discussion will be based solely on the Norwegian case because I shall question the appropriateness of "local self-government" in this particular context. But even if my arguments arise from a single European case, the discussion does have a wider European relevance partly because the observed trends in contemporary governing are common to most European countries, and partly because the Council of Europe intends to revise the mentioned Charter in the years to come (Loughlin, 2009:11). 
In the first part, the article discusses contemporary trends related to the concept of integration because vertical integration is a well-established term used to explain the relation between local and central government in a welfare state such as Norway. I will argue that in later years, this vertical integration has been increasingly mixed with a more horizontal type of integration. This type corresponds to what has become known as co-governance, and the pertinent theoretical literature frames the discussion about empirical examples of co-governance and challenges that arise from this development.

In conclusion, I will argue that the very basic concept of local self-government, indicated in the $\mathrm{CoE}$ Charter, does not necessarily give us any clear direction nor does it necessarily make any sense in a political system clearly characterised by co-governance. Stating the principle of local self-government in the constitution may still be seen as a meaningful symbolic act. But to the extent that this symbolism occurs at the expense of other crucial problems raised by cogovernance related for example to accountability and democracy, one can argue that dealing with "self-government" too much and for too long is a dead end. In the final section, I will point to some questions and issues that a revised version of the CoE Charter may deal with.

\section{Vertical and Horizontal Integration}

The question about constitutional local self-government in Norway can be approached in at least two different ways. Seen in a comparative perspective, it is clear that in some important respects, Norway represents an exception because most corresponding welfare states do have some kind of constitutional protection of their local governments (Sellers \& Lidström, 2007:618). Even if one can argue that Norwegian local self-government does have a status based on traditions and informal norms (Grønlie, 2004), in this context, formally Norway belongs to the group of countries that only seldom relate themselves, e.g., to Italy, Great Britain, and Australia (Sellers \& Lidström, 2007:617). In this perspective, a constitutional protection of local self-government should mean to protect the practice that is already well established in Norway.

On the other hand, this point of view may also be questioned, e.g., by asking to what extent a stronger emphasis on local self-government actually corresponds to the present practice, and what kind of practical implications a potential constitutional change may have. Such a discussion of the balance between principles and practice was the central theme of the discussion prior to the new Local Government Act of 1992 (Kjellberg, 1995). It will provide the basis for the subsequent discussion.

The debate in the legislation process mainly pointed to the close relationship between the central and local government that had developed within the modern welfare state. This vertical integration, as conceptualised by Kjellberg (1985; 
1988; 1995), has later been supplemented with more horizontal integration. In some respects more than before, Norwegian local government interacts with other public and private actors in order to govern and develop their locality and region. When returning to them later on, we may conceptualise this type of steering and interaction as co-governance (Somerville \& Haines, 2008).

The political discussion concerning the constitutional protection of local selfgovernment has a parallel in the old academic discourse about the values inherent in self-government, commonly conceptualised as autonomy, democracy and effectiveness (Sharpe 1970; Kjellberg 1995). According to this widespread view, local government gets its legitimacy through autonomy from central government, through its contribution to democracy, and partly through its closeness to its local citizens and problems, presumably bringing more effective solutions to local problems than in the case of the central state.

Even if one can easily accept these positive values, they cannot necessarily be realized in parallel, or simultaneously met to a similar extent. In the real world, these values may conflict (Kjellberg, 1995:42). Any state that looks for an appropriate local government system will to a certain extent have to seek a balance between different values. When comparing different local government systems worldwide, it is clear that different countries have found different ways of balancing these values (Page \& Goldsmith, 1987; Denters \& Rose, 2005).

When turning back to Norway, one might assert that the proposal about a constitutional change as mentioned in the introduction, clearly stating the principle of local self-government in the constitution, would mean strengthening the value of autonomy, at least symbolically. This value was also the decisive argument behind "Formannskapslovene" in 1837, the act that introduced municipalities in Norway because there was a major concern how to restrict the power of senior state officials in local communities. The act was seen as an answer to the claim for more shared power between government levels and local autonomy to allow local communities to influence their development and future. It was a "clear expression of the liberal or liberalistic notion of the limited and passive state" (Kjellberg, 1995:42).

In recent times, however, the reasoning about autonomy has changed because with the modern welfare state, it is not so much a question of autonomy from the state as a question of autonomy to do something, e.g., to take action in order to meet local challenges and to solve local problems.

When comparing the proposal about constitutional protection of local selfgovernment to some of the reforms made by the Norwegian Parliament in later years, some contrasting trends inevitably occur. Most importantly, the Local Government Act was revised in 1992. The ambition of the Act was "to make provision for functional democracy in local government, and for efficient and 
effective management of the common local government interests within the framework of a national community, and with a view to sustainable development" (Article 1 of the Local and Regional Government Act, 25 September 1992). The wording was carefully selected. It was meant to mirror the close interaction that had occurred with the modern welfare state where local government was responsible for implementation of a range of important core services (Kjellberg, $1985 ; 1988)$.

Over the 15-year period after revising the Local Government Act, the close interaction between local and central government has been upheld. Undoubtedly, the Norwegian system is characterised by vertical integration, politically intended, and closely related to the functioning of the Norwegian welfare system (Røiseland, Jenssen \& Aarsæther, 2008). As a result, any real change in the direction of more local self-government will inevitably lead to more spatial variation in the next turn to conflict with other popular values such as individual rights in welfare policies, national quality, and fair distribution among localities and regions (Tranvik \& Fimreite, 2006). Vertical integration was an important background for the new Act in 1992, and the support given to such a type of integration, not least from the central ministries, is hardly less important today. It is basically rooted in the welfare state system of Norway.

But we can also observe another kind of integration, more common now than 15 years ago. This is a horizontal type of integration in the form of shared power between public and private actors in the Norwegian localities and regions. This type of integration is often related to development issues. These kinds of local policies have become increasingly important during the last few years. Today there are widespread expectations, formal and informal, directing local and regional governments to engage in issues and problems that can hardly be solved within the frame of the same institutions. To become successful, modern city planning, business development, social planning and place marketing imply some form of co-operation that exceeds the boundaries of public government.

In international literature, this development perceived in the direction of horizontal integration corresponds either to the claimed shift from "government" to "governance" (Rhodes, 1997; Sørensen \& Torfing, 2005) or to the observation that old and new models co-exist in a "hybrid state" in widely varying combinations (Loughlin, 2009: 68). These new models have also been conceptualised, e.g., as interactive governance (Buuren, Edelenbos, and Klijn 2007), network governance (Marcussen \& Torfing, 2007), and co-governance (Somerville \& Haines, 2008; Kickert \& Koppenjan, 1997; Johnson \& Osborne 2003).

When dealing with a large body of theoretical and conceptual literature, there is a certain risk of conceptual confusion. In the following discussion, the traditional 
hierarchical model is conceptualised as government doing governing, whereas the trends towards less hierarchical models are conceptualised as co-governance.

The notion of co-governance points to the observation that today's local governments regularly govern together with other kinds of actors, e.g., through different types of collaboration with local businesses, voluntary organisations or neighbouring municipalities. Kooiman describes co-governance as a new form of steering that can be denoted as doing things together instead of doing them alone either by the state or by the market (1993:1; see also Kickert \& Koppenjan, 1997: 40 ), whereas Johnson and Osborne tend to understand co-governance in relation to power-sharing and "negotiating government" (2003:147-149).

In the political debate, this development in the direction of horizontal integration or co-governance has not been as clearly articulated as that of the vertical type mentioned above (Røiseland, 2008), but these developments influence the autonomy of local government as much as vertical integration. This needs to be taken into account when discussing constitutional protection of local selfgovernment. In the next section, I shall explain this type of integration in more detail by providing some examples.

Figure 1: Typology of co-governance involving Norwegian local government

\begin{tabular}{|l|c|c|}
\hline \multirow{2}{*}{ One or more levels? } & \multicolumn{2}{|c|}{ One or more sectors? } \\
\cline { 2 - 3 } $\begin{array}{l}\text { One level } \\
\text { (local government) }\end{array}$ & $\begin{array}{c}\text { One sector, } \\
\text { i.e., public only } \\
\text { i.e., public and market } \\
\text { and/or civil society }\end{array}$ \\
& $\begin{array}{c}\text { Type 1 } \\
\text { Inter-municipal } \\
\text { co-operations } \\
\text { Inter-municipal } \\
\text { companies }\end{array}$ & $\begin{array}{c}\text { Type 2 } \\
\text { Projects or committees, } \\
\text { e.g., in planning, } \\
\text { Partnerships or limited } \\
\text { companies. }\end{array}$ \\
\hline $\begin{array}{l}\text { Several levels } \\
\text { (local government and } \\
\text { regional and/or national } \\
\text { level) }\end{array}$ & $\begin{array}{c}\text { Type 3 } \\
\text { Collaborations/proje } \\
\text { cts for infrastructure } \\
\text { (e.g., roads, railway, } \\
\text { shipping), New Welfare } \\
\text { Organisation (NAV) }\end{array}$ & $\begin{array}{c}\text { Regional development } \\
\text { programmes conducted } \\
\text { by regional government }\end{array}$ \\
\hline
\end{tabular}


As illustrated in Figure 1, co-governance is performed by different kinds of institutional structures, ranging from formal organisations (e.g., limited companies) to looser networks. Figure 1 also shows that co-governance exists both within the public sector and across societal sectors (public, private, civil).

The first type of co-governance involves the public sector only, i.e., local government. The most typical examples are different kinds of inter-municipal cooperation or companies. The next type comprises forms of collaboration where local governments act together with market actors or civil society limited by the geographical area served by the municipality. Some typical examples of these cogovernance arrangements are found in local planning processes where projects and committees often include non-public actors. Additionally, a number of boards and committees exist. Some of them are imposed by law, e.g., the boards for the elderly and handicapped. This type of co-governance also includes collaboration related to running the services and projects organised as partnerships or limited companies.

The third type of co-governance, corresponding to joined-up government (Goldsmith \& Eggers, 2004), is typical in infrastructure and transport policies because formal responsibilities for different kinds of transport, roads and shipping are spread across the three levels of government, and collaboration is often needed to make seamless services and operations. This model has also been chosen in an ongoing labour and welfare administration reform where local offices are partly run by the central government (labour and pension issues) and partly by local government (social care) in a mandatory partnership agreement between central and local government (Fimreite \& Lægreid, 2009).

Finally, type four includes extensive border crossings in that several sectors and levels are involved. Since the late 1990s, this type of co-governance has been the regional policy forming principle so that every regional government is expected to carry out a plan for regional development in collaboration with a number of other actors representing business life, local government, and the state (Halkier and Gjertsen 2004).

When trying to measure these forms of co-governance quantitatively, we face serious obstacles partly because some of the institutional forms, e.g., looser networks, makes them hard to register and count, and partly because the lack of attention from the state authorities means there is no common database of cogovernance types that could, in principle, be easily counted. Still there are clear indications that the amount of co-governance is considerable. It represents a trend that needs to be taken into account. One example is the growing number of limited companies operating on behalf of local governments, but often having local government as only one of many owners (Ringkjøb, Aars \& Vabo, 2008). 
At present, limited companies seem to be the preferred organisational form for cogovernance. It represents the framework for cooperation with market actors and neighbouring municipalities. Inter-municipal collaboration exemplifies cogovernance with various organisational forms, ranging from more or less informal oral or written agreements on cooperation to very formal collaborations with intermunicipal companies. The latter resembles limited companies, but they are open only to municipalities in accordance with the Local Government Act (Article 27). Other examples refer to the regional development programmes mentioned above (Mariussen et al., 2000), and to the corresponding initiatives in business development and planning both locally and regionally (Bukve, Halkier \& Souza, 2008).

And finally, even if it is hard to register and count, a recent empirical study in three Norwegian cities reveals that also the more informal types of co-governance can be extensive, e.g., informal meeting places for the local government leadership, business organisation leaders, and leaders of large companies (Kristiansen, 2007; Vabo, 2007; Røiseland, 2007).

\section{Co-Governance as an Option and Problem}

One cannot assert that co-governance represents a new phenomenon. Quite the opposite, co-governance can be understood as a core characteristic of the Nordic society model, combining a strong state, extensive market economies, and a lively civil society (Marcussen \& Torfing, 2007). This unusual combination has been possible only to the extent that one has been able to link together the different societal sectors in governing the society. Still, one can argue that the classic corporate model associated with the Nordic countries represents a system dominated by a hierarchical central government, whereas co-governance and the corresponding concepts stand for a more pluralistic and society-based model of governance (Mörth \& Sahlin-Andersson, 2006: 151; Kersbergen \& Waarden, 2004).

Among public leaders, co-governance increasingly represents an ideal model for governing (Sørensen and Torfing 2007; Haveri et al. 2009). This is demonstrated in several ways, e.g., through a legal framework for public decision-making that, to an increasing extent, promotes co-governance. In Norway, this has led to new legal rules allowing inter-municipal collaboration in various institutional forms. Generally, one tends to see this trend as arising from the growing complexity caused by urbanisation and globalisation (Denters \& Rose, 2005; Sørensen \& Torfing, 2005).

In the long run, any democratic political system presupposes that public authorities are able to meet collective needs and solve collective problems. Having in mind that western societies have gone through some heavy societal changes during the last generation, we may see co-governance and horizontal integration as 
an appropriate response and adaptation to the problems and challenges we expect governments to deal with (Pierre \& Peters, 2000; Bogason, 2000). From this point of view, there is every reason to believe that co-governance has an added value that surpasses more traditional hierarchical modes of governing, and that cogovernance delivers results, unlike other modes. And, conversely, having in mind that collaboration is a complex and costly activity (Huxham \& Vangen, 2005), no local or regional government will choose this mode of governing if they can avoid it.

Relating these observations to the constitutional proposal in the Norwegian Parliament discussed above, one can argue that to a certain extent, there is a tension between reality and ideology in the perception of autonomy. Even if autonomy was the decisive value when the Norwegian municipalities were formed in 1837, this type of autonomy was left behind somewhere in the 1960s, and formally abolished in the legislation process ending with the new 1992 Act as a result of vertical integration (Larsen \& Offerdal, 2000). The growing horizontal integration mentioned above shows that any idea about extensive local autonomy seems more far away than ever.

Even if co-governance takes place in the shadow of hierarchy (Scharpf, 1994, Pierre \& Peters, 2000; 2005), allowing traditional political institutions to have the final word, it is still something that needs to be taken into account. Proceeding from a lack of clear hierarchy among the actors involved in co-governance, the accessible steering tools are different and limited, forcing governments to exercise what has been conceptualised as "network management" (Agranoff, 2006) or "metagovernance" (Sørensen \& Torfing, 2008).

Co-governance does not only challenge public authorities' capacity for traditional governing, but it may also raise other problems. For instance, despite interdependent actors involved in co-governance, these actors uphold their operational autonomy, and they are usually free to withhold collaboration if the results are not as expected. This means that co-governance may break down in conflicting settings where power and influence are at stake, and the involved actors see no common benefits of further collaboration. One may formulate this as a paradox because, on the one hand, democratic politics is basically to overcome conflicts and opposing interests, but on the other hand, a conflict is the basic obstacle to successful co-governance (Agranoff ,2006). Co-governance is therefore more a strategy for easy summer days than for hard winter nights. There is a lack of experience and knowledge about what happens when winter sets in.

In addition, several problems related to democracy can be raised. One common objection to co-governance is the assertion that this type of steering threatens the logic of the parliamentary chain, and, therefore, it threatens democracy itself (Selle \& Østerud, 2006). Problems arise because there is no mechanism for accountability in place when decisions are taken well away from the 
representative system. Co-governance does not give equal participatory rights. And the lack of visibility and openness may represent a problem (Greenaway, Salter \& Hart, 2007).

On the other hand, it is not obvious what kind of reference point or democratic criteria co-governance needs to meet. When discussing network governance, Sørensen and Torfing (2007) argue that public visibility and political representation are two crucial factors for the anchorage in democracy. But this is an area not very well researched, and where a new literature review reveals that in Nordic research, these issues are discussed to a very limited extent (Ringholm 2007).

\section{From Local Self-Government to Local Self-Governance?}

The discussion above took departure in the proposal about introducing the constitutional protection of local self-government in Norway. When viewed in the perspective presented above, pointing to vertical and horizontal integration, it is not obvious whether understanding local government as a single delimited institution makes sense or it gives a substantial meaning. Furthermore, the concept of "local self-government" gives meaning only to the extent that "local government" does.

This rather pessimistic conclusion may, however, be met by two opposing arguments. Firstly, one may argue that clear stating of "local self-government" in the constitution can be understood as an important symbolic act, which in a given future situation, if not necessarily important or clearly meaningful today, may be of great importance in order to keep local democracy. Such an argument can hardly be rejected. But it is important that political leaders are aware of the difference between such a constitutional ideal and the real world.

Secondly, one may argue that there is just a tiny difference between meaning and meaninglessness in the sense that if one replaces "government" with "governance", local self-governance would point to the conditions and capacities that localities and local communities have to influence their development and future, partly through traditional hierarchical steering by local government, partly through various co-governance arrangements. Such an interpretation to some extent resembles what the intention originally was when Norwegian municipalities were formed long ago. It directs attention towards local democratic participation and the need to anchor local development in local democracy. However, as the responsible minister clearly has stated that what one intends to protect is the municipal institution (Kleppa, 2007), there is no reason to see this type of autonomy as a part of the Norwegian discussion.

The European Charter of Local Self-Government, adopted in the early 1980s, has had a significant impact on local government development in Europe, and has 
probably served as a roadmap for the new democracies in the East. When revising the Charter, one needs to account for the developments described above. This does not necessarily mean that one ought to give up the whole idea about local selfgovernment, but a new Charter may provide some European standards of accountability and democracy in co-governance. What are the standards, to take one example, that co-governance needs to meet in order to be democratic? Do all possible stakeholders need to be involved? Are some kinds of formal mechanisms for placing accountability on given actors the essence of democracy? Or does democracy means that elected representatives are involved in the governance processes? Obviously, one cannot expect the European Charter to clearly answer these questions, but a future Charter may provide some basic European guidelines on how to deal with them.

\section{References}

Agranoff, R. (2006) Inside collaborative networks: Ten lessons for public managers, Public Administration Review, 66(1), pp. 56-65, doi: 10.1111/j.1540-6210.2006.00666.x.

Bogason, P. (2000) Public Policy and Local Governance. Institutions in postmodern society (Cheltenham: Edward Elgar).

Bukve, O., Halkier, H. \& De Souze, P. (eds.) (2008) Towards New Nordic Regions. Politics, Administration and Regional Development (Aalborg: Aalborg Universitetsforlag).

Buuren, A., Edelenbos, J. \& Klijn, E. H. (2007) Interactive governance in the Netherlands: The case of the Scheldt Estuary, In: Marcussen, M. \& Torfing, J. (eds.) Democratic network governance in Europe (Hampshire: Palgrave).

Council of Europe (1985) European Charter of Local Self-Government (Strasbourg: Council of Europe), 15.10 .1985$.

Denters, B. \& Rose, L. E. (eds.) (2005) Comparing local governance. Trend and developments (Houndmills: Palgrave MacMillan).

Fimreite, A. L. \& Lægreid, P. (2009) Reorganizing the welfare administration, Public Management Review, 11(3), pp. 281-297.

Goldsmith, S. \& Eggers, W. D. (2004) Governing by network. The new shape of the public sector (Washington D.C.: Brookings Institutions Press).

Greenaway, J., Salter, B. \& Hart, S. (2007) How policy networks can damage democratic health: A case study in the government of governance, Public Administration, 85 (3), pp. 717-738.

Grønlie, T. (2004) Fra velferdskommune til velferdsstat - hundre års velferdsvekst fra lokalisme til statsdominans, Historisk Tidsskrift, 83(4), pp. 633-649.

Halkier, H. \& Gjertsen, A. (2004) Regional development through partnership in Norway and Denmark, In: Dosenrode, S. \& Halkier, H. (eds.) The Nordic Regions and the European Union (London: Ashgate).

Haveri, A., Nyholm, I., Røiseland, A. \& Vabo, I. (2009) Governing collaboration: Practices of meta-governance in Finnish and Norwegian local governments, Local Government Studies, 35(5), pp. 539-556, doi: 10.1080/03003930903227360.

Huxham, C. \& Vangen, S. (2005) Managing to collaborate. The theory and practice of collaborative advantage (London: Routledge).

Johnson, C. \& Osborn, S. P. (2003) Local strategic partnerships, neighbourhood renewal, and the limits to co-governance, Public Money \& Management, 23(3), pp. 147-154.

Van Kersbergen, K. \& Van Waarden, F. (2004) Governance as a bridge between disciplines: Cross-disciplinary inspiration regarding shifts in governance and problems of governability, 
accountability and legitimacy, European Journal of Political Research, 43(2), pp.143-171, doi: 10.1111/j.1475-6765.2004.00149.x.

Kickert, W. J. M. \& Koppenjan, J. F. M. (1997) Public management and network management: An overview, In: Kickert, W. J. M., Klijn, E. H. \& Koppenjan, J. F. M. (eds.) Managing complex networks. Strategies for public sector (London: Sage).

Kjellberg, F. (1988) Local government and the welfare state. Reorganization in Scandinavia, In:

Dente, B. \& Kjellberg, F. (eds.) The dynamics of institutional change. Local government reorganisation in western democracies (London: Sage Publications).

Kjellberg, F. (1985) Local government - organization and the development of the welfare state, Journal of public policy, 5(2), pp. 215-239.

Kjellberg, F. (1995) The Changing Values of Local Government, Annals of the American Academy of Political and Social Science, 50(July 1995), pp. 40-50.

Kleppa, M. M. (2007) Lokalt sjølvstyre og grunnlova: Kva skjer? Stat og styring, 2007(4), pp. 28 29.

Kooiman, J. (ed.) (1993) Modern governance: New government-society interactions (London: Sage).

Kristiansen, R. (2007) Styringsnettverk $i$ Narvike (University of Tromsø: Working paper).

Larsen, H. O. \& Offerdal, A. (2000) Political implications of the new Norwegian Local Government Act of 1992, In: Amnå, E. \& Montin, S. (eds.) Towards a new concept of local selfgovernment? (Bergen: Fagbokforlaget).

Loughlin, J. (2009) The "hybrid" state: Reconfiguring territorial governance in Western Europe, Perspectives on European politics and society, 10(1), pp. 51-68, doi: 10.1080/15705850802700009.

Loughlin, J. (2009) Regional and local governance in the 21st century: challenges and opportunities, Paper presented at Conference: Innovation for good local and regional governance - A European challenge, at University of Twente, Enchede, The Netherlands, $2^{\text {nd }}$ April, 2009.

Marcussen, M. \& Torfing, J. (eds.) (2007) Democratic network governance in Europe (Hampshire: Palgrave).

Mariussen, A.., Gjertsen, A., Røiseland, A. \& Sandersen, H. (2000) Evaluering av regionale utviklingsprogram i Norge (Stockholm: Nordregio).

Mörth, U. \& Sahlin-Andersson, K. (2006) Privatoffentliga partnerskap. Styrning utan hiearkier och tvaing? (Stockholm: SNS Förlag).

Page, E. C. \& Goldsmith, M. J. (eds.) (1987) Central and local government relations. A comparative analysis of West-European unitary systems (London: SAGE).

Parsons, W. (1995) Public Policy. An introduction to the theory and practice of policy analysis (Cheltenham, UK: Edward Elgar).

Pierre, J. \& Peters, B. G. (2000) Governance, politics and the state. Political analysis (London: MacMillan).

Rhodes, R. A. W. (1997) Understanding governance. Policy networks, governance, reflexivity and accountability (Maidenhead: Open University Press).

Ringholm, T. (ed.) (2007) Taking stock of national research on Networked Governance. The case of Norway, Working paper 8 (Roskilde: Centre for democratic network governance, Roskilde University).

Ringkjøb, H. E., Aars, J. \& Vabo, I. S. (2008) Lokalt folkestyre AS. Eierskap og styringsroller $i$ kommunale selskap, Rapport 1-2008 (Bergen: Rokkansenteret).

Røiseland, A. (2007) Styringsnettverk i Steinkjer (Bodø University College: Working paper).

Røiseland, A., Synnøve, J. \& Aarsæther, N. (2008) Local governance and the challenges of global change, In: Aarsæther, N., Røiseland, A. \& Jenssen, S. (eds.) Practising local governance. Northern perspectives (New York: Nova Science Publishers).

Selle, P. \& Østerud, Ø. (2006) The eroding of representative democracy in Norway, Journal of European Public Policy, 13(4), pp. 551-568. 
Sellers, J. M. \& Lidström, A. (2007) Decentralization, local government, and the welfare state. Governance: An International Journal of Policy, Administration, and Institutions, 20(4), pp. 609-632, doi: 10.1111/j.1468-0491.2007.00374.x.

Sharpe, L. J. (1970) Theories and values of local government, Political Studies, 18(2), pp. 153-74, 10.1111/j.1467-9248.1970.tb00867.x.

Somerville, P. \& Haines, N. (2008) Prospects for Local Co-Governance, Local Government Studies, 34 (1), pp. 61 - 79, doi: 10.1080/03003930701770488.

Sørensen, E. \& Torfing, J. (2005) The Democratic Anchorage of Governance Networks, Scandinavian Political Studies, 28(3), pp. 195-218.

Sørensen, E. \& Torfing, J. (2005) Netvarksstyring: fra government til governance (Frederiksberg: Roskilde Universitetsforlag).

Sørensen, E. \& Torfing, J. (2008) Making governance networks effective and democratic through metagovernance, Public Administration, 87(2), pp. 234-258, doi: 10.1111/j.14679299.2009.01753.x.

Sørensen, E. \& Torfing, J. (2007) Theoretical approaches to democratic network governance, In: Sørensen, E. \& Torfing, J. (eds.) Theories of democratic network governance (Houndmills, Basingstoke, Houndmills: Palgrave).

Sørensen, E. \& Torfing, J. (eds.) (2007) Theories of democratic network governance (Houndmills, Basingstoke, Houndmills: Palgrave).

Tranvik, T. \& Fimreite, A. L. (2006) Reform failure: The processes of devolution and centralisation in Norway, Local Government Studies, 32(1), pp. 89-107, doi: 10.1080/03003930500453609.

Vabo, S. I. (2007) Styringsnettverk i Drammen (Oslo University College: Working paper).

\section{Acknowledgements}

The article is based on research funded by the Norwegian Research Councils program on "Democracy, Governance and Regionalism". The author wishes to thank Signy Vabo, Oslo University College, for fruitful discussions and valuable comments on earlier drafts. 